\title{
PERCONTOHAN BUDIDAYA KEDELAI HITAM DI LAHAN SAWAH DESA KEMUMU DAN OLAHAN HASILNYA
}

\author{
Bambang Gonggo Murcitro ${ }^{1}$, Hesti Pujiwati ${ }^{2}$, Tuti Tutuarima ${ }^{3}$ \\ 1,2,3 Universitas Bengkulu \\ 1'bgonggo@unib.ac.id, ${ }^{2}$ hestipujiwati@unib.ac.id, ${ }^{3}$ tutitutuarima@unib.ac.id
}

\begin{abstract}
This devotional activity aims to improve farmers' skills in the cultivation of black soybeans and increase the selling value of black soybeans which can ultimately increase farmers' incomes in Keтити Village. Devotional activities are designed in 3 types of activities that are mutually sustainable, namely (1) education and extension of black soybeans, (2) the manufacture of black soybean planting experiments, and (3) training and the making of black soybean processing. The results of the activity showed that the education and counseling carried out by the devotional team was able to increase knowledge about black soybeans both planting techniques and processing of seed products. Cultivation of soybean plants and the manufacture of processed soybean seeds into tempe, tofu, and soy sauce have been successfully carried out by the farmer's group of Kemumu Village, North Bengkulu. The result achieved by the black soybean variety Detam 4 is 1.39 tons/ha. To follow up on this activity, the proposed suggestions include: (1) in the future members of the target farming group are expected to continue to carry out the practice of cultivating black soybeans on a wider scale (2) members of the target farming group to keep making tempe and soybeans on an industrial scale to increase household income, (3) to the government to provide a channel of funds to meet adequate equipment resources in the production of tofu and industrial-scale tempe.
\end{abstract}

Key words: soybean, tofu, tempe, soy sauce

\section{PENDAHULUAN}

Desa Kemumu termasuk wilayah Kecamatan Kota Arma Jaya Kabupaten Bengkulu Utara Provinsi Bengkulu. Kelurahan Kemumu termasuk kategori daerah dataran tinggi. Sebagian besar wilayahnya memiliki topografi dataran dan berbukit. Kelurahan Kemumu berada pada ketinggian 11,4 m dari permukaan air laut dan mempunyai luas wilayah secara keseluruhan $298.754 \mathrm{~m}^{2}$. Curah hujan rata- rata berkisar antara $2000 \mathrm{~mm}$ sampai dengan $3000 \mathrm{~mm}$ dengan suhu rata-rata $32^{\circ} \mathrm{C}$. Mayoritas penduduk desa bermata pencaharian sebagai petani yaitu sebanyak $75.14 \%$ dari 346 jiwa atau 260 jiwa, perkebunan $14.45 \%$ atau 50 jiwa, sedangkan yang berdagang $2.89 \%$ atau 10 jiwa dan PNS (Pegawai Negeri Sipil) sebanyak $7.52 \%$ atau 26 jiwa.

Desa Kemumu memiliki potensi besar untuk dilakukan pengambangan budidaya tanaman kedelai. Hal tersebut mengingat Desa Kemumu memiliki sawah yang cukup luas dengan saluran irigasi yang baik. Budidaya kedelai hitam untuk melakukan rotasi pertanaman padi sawah bisa berdampak baik berupa putusnya siklus hidup hama dan penyakit padi.

Kedelai hitam (Glycine max (L.) Merrill) merupakan salah satu jenis komoditas hortikultura yang sangat digemari masyarakat, kedelai hitam dapat diolah menjadi kecap, campuran peyek dan sebagai obat. Kandungan yang terdapat pada kedelai hitam menjadikan kedelai hitam pangan yang ideal bagi penderita diabetes melitus (Zakaria et al., 2016). Dalam 100g kedelai mengandung energi $381 \mathrm{kkal}$, protein $40 \mathrm{~g}$, lemak $12,7 \mathrm{~g}$ dan karbohidrat 24,9 g (Tanuwijaya et al., 2016). Kedelai hitam memiliki kandungan flavonoid dalam bentuk isoflavon dan antosianin yang nilainya lebih tinggi dari kedelai kuning sehingga aktivitas antioksidannya juga lebih tinggi (Devi et al., 2009, Jeng et al., 
2010; Irwanto et al. (2016). Kedelai hitam bermanfaat pada penderita Diabetes Melitus dengan meningkatkan serum insulin dan komponen insulin pankreas (Mueller, 2012). Peningkatan jumlah penduduk serta banyaknya industri pengolahan makanan berbahan kedelai hitam yang secara pasti meningkatkan kebutuhan akan kedelai hitam. Beberapa indutri makanan yang berbahan baku kedelai hitam diantaranya adalah tempa (Astuti et al., 2009), tahu (Indrawijaya et al., 2017), dan kecap (Muangthai et al., 2009).

Petani di Desa Kemumu telah akrab dengan budidaya tanaman pangan maupun tanaman hortikultura. Beberapa petani di Desa Kemumu sudah membudidayakan kedelai namun produktivitasnya rendah sehingga tidak menutupi biaya produksi. Selain itu harga jual kedelai di pasaran juga rendah. Untuk mengatasi permasalahan rendahnya produktivitas kedelai di lahan dan rendahnya harga jual kedelai di Kemumu salah satunya adalah memberi pelatihan yang berupa demplot budidaya kedelai dan memberikan penyuluhan tentang praktek pengolahan kedelai hitam menjadi tahu, tempe dan kecap. Sehingga diharapkan dapat meningkatkan keterampilan petani dalam budidaya kedelai hitam dan meningkatkan nilai jual kedelai hitam yang pada akhirnya dapat meningkatkan pendapatan petani di Desa Kemumu.

\section{METODE}

Kegiatan pengabdian dilakukan di Desa Kemumu Kabupaten Bengkulu Utara. Kegiatan pengabdian dilaksanakan pada bulan Mei - November 2020. Pelaksanaan pembuatan demplot dan pengolahan kedela dilakukan dengan cara membagi petani menjadi 2 kelompok (masing-masing kelompok terdiri dari 15 orang), kemudian masing-masing kelompok diberi pengarahan tentang budidayadan penolahan kedelai hitam. Pengabdian kepada masyarakat ini dirancang dalam 3 jenis kegiatan yang saling berkesinambungan yaitu (1) pendidikan dan penyuluhan kedelai hitam, (2) pembuatan demplot percobaan penanaman kedelai hitam, serta (3) pelatihan dan pembuatan olahan kedelai hitam.

Kegiatan pendidikan dan penyuluhan dilakukan dengan tujuan untuk menambah wawasan dan memperkaya cara berfikir kelompok tani serta anggotanya tentang kedelai hitam. Adapun materi yang disampaikan dalam kegiatan ini adalah tentang kedelai hitam yang meliputi kandungan gizi, manfaat, syarat tumbuhnya, cara membudidayakannya serta cara mengolah hasil biji kedelai hitam. Setelah petani memahami budidaya kedelai maka dilakukan percobaan demplot di lapangan. Demplot di petani dilakukan pada lahan seluas 0.25 ha dengan tahapan pengolahan lahan, penanaman, pemeliharaan tanaman, dan panen. Setelah kedelai dipanen maka dilanjutkan kegiatan pengolahan biji kedelai menjadi produk tahu dan tempe.

\section{HASIL KARYA UTAMA DAN PEMBAHASAN}

A. Pendidikan dan Penyuluhan Kedelai Hitam

Kegiatan pengabdian diawali dengan survey lapangan dalam rangka menentukan lokasi kegiatan yang dilakukan Januari 2020. Selanjutnya dilakukan koordinasi dengan kepala desa dan ketua kelompok tani untuk menentukan waktu dan lokasi sosialisasi dan pelatihan. Kegiatan sosialisasi dan pelatihan dilaksanakan pada 10-11 Mei 2021 yang dihadiri oleh 30 orang anggota kelompok tani. Secara berturut-turut kepada kelompok tani sasaran diberikan pemahaman tentang kedelai hitam, kandungan gizi dan manfaatnya, teknik budidaya serta pembuatan produk olahan. Sebelum dan sesudah dilakukan sosialisasi terlebih dahulu diukur pengetahuan kelompok tani sasaran tentang kedelai hitam menggunakan koesioner yang berisi pernyataan dengan pilihan jawaban menggunakan skala likert (Tabel 1 dan Tabel 2). 
PEDULI: Jurnal Ilmiah Pengabdian Pada Masyarakat, 2021, Vol.5, No.2

ISSN: 25974653. EISSN:25974688

http://peduli.wisnuwardhana.ac.id/index.php/peduli/index

Tabel 1. Pengetahuan terhadap kedelai hitam sebelum kegiatan pendidikan dan penyuluhan

\begin{tabular}{lcc}
\hline \multicolumn{1}{c}{ Pernyataan } & Rata-Rata Skor & Interprestasi \\
\hline Pengetahuan tentang kedelai hitam & 1,52 & Tidak Tahu \\
Pengetahuan tentang budidaya kedelai hitam & 1,86 & Kurang Tahu \\
Menanam kedelai hitam & 1,00 & Tidak Pernah \\
Pengetahuan tentang pengolahan kedelai hitam & 2,05 & Kurang Tahu \\
\hline
\end{tabular}

Berdasarkan Tabel 1 terlihat bahwa hampir sebagian besar kelompok tani sasaran belum mengetahui informasi apapun tentang tanaman kedelai hitam dengan rata-rata skor sebesar 1,52 yang tergolong dalam kriteria "tidak tahu". Hal tersebut sangat wajar karena selama ini mereka hanya mengetahui kedelai kuning, sedangkan kedelai hitam belum bagi mereka merupakan komoditi yang relatif baru bahkan belum pernah melihat langsung bijinya. Sebagian besar kelompok tani sasaran kurang tahu bagaimana cara membudidayakan kedelai hitam dengan rata-rata skor 1,86 . Seluruh anggota kelompok tani sasaran sama sekali belum pernah menanam kedelai hitam. Selanjutnya sebagian besar kelompok tani sasaran juga kurang mengetahui cara pengolahan kedelai hitam.

Tabel 2. Pengetahuan terhadap kedelai hitam setelah kegiatan pendidikan dan penyuluhan

\begin{tabular}{lcc}
\hline \multicolumn{1}{c}{ Pernyataan } & Rata-Rata Skor & Interprestasi \\
\hline Kejelasan informasi tentang kedelai hitam & 3,36 & Jelas \\
Kelebihan dan manfaat kedelai hitam & 3,15 & Cukup Jelas \\
Kesesuaian keadaan desa dengan kedelai hitam & 3,51 & Sesuai \\
Minat menanam kedelai hitam & 2,98 & Cukup Berminat \\
Kemudahan pembuatan olahan kedelai hitam & 3,28 & Mudah \\
\hline
\end{tabular}

Setelah dilakukan sosialisasi, terdapat perbedaan antara hasil penilaian pengetahuan pada Tabel 1 dan Tabel 2. Berdasarkan Tabel 2 menunjukkan bahwa kegiatan sosialisasi yang dilakukan oleh tim pengabdian memberikan kejelasan informasi tentang tanaman kedelai hitam. Anggotan kelompok tani sasaran yang semula tidak tahu sama sekali tentang kedelai hitam menjadi tahu. Hal tersebut terlihat dari indikator kejelasan informasi tentang kedelai hitam memiliki skor rata-rata sebesar 3,36 yang termasuk dalam kriteria jelas. Hasil penelitian yang selaras juga dilaporkan oleh Yanti et al. (2017) bahwa kegiatan pengabdian yang dilakukan telah mampu mengedukasi masyarakat khsusnya petani sekitar tentang budidaya tanaman palawija dengan aplikasi rizobakteri indigenos.

Berdasarkan Tabel 2 juga terlihat bahwa kelebihan dan manfaat tanaman kedelai hitam tersebut yang belum sepenuhnya dipahami dengan jelas oleh masyarakat (cukup jelas tapi mendekati jelas). Hal ini terlihat dari indikator pernyataan kelebihan dan manfaat kedelai hitam memiliki rata-rata skor sebesar 3,15 yang tergolong cukup jelas. Menurut beberapa anggota kelompok tani sasaran hal ini dikarenakan informasi tentang kelebihan dan manfaat tanaman kedelai hitam yang diperoleh hanya sebatas pemaparan dari tim pengabdian, sedangkan manfaat nyatanya terutama dibidang ekonomi belum dirasakan langsung oleh masyarakat. Hal tersebut terlihat dari persepsi anggota kelompok sasaran bahwa manfaat ekonomi yang akan didapat dari tanaman kedelai hitam masyarakat menilai masih ragu-ragu karena belum benar-benar dilakukan dan belum adanya kepastian pasar dimana akan dijual hasil panennya nanti.

Setelah dilakukan pemaparan tentang syarat tumbuh tanaman kedelai hitam terlihat bahwa sebagian besar petani menganggap bahwa desa mereka cocok untuk budidaya tanaman kedelai hitam. Hal tersebut terlihat dari indikator pernyataan kesesuaian keadaan desa dengan kedelai hitam yang memiliki rata-rata skor sebesar 3,51 yang tergolong "sesuai".

Selaras dengan persepsi anggota kelompok tani sasaran tentang, manfaat dan pengetahuan yang kedelai hitam mereka dapatkan, maka kesediaan untuk mengikuti dan 
berpartisipasi dalam program pemberdayaan menjadi faktor kunci keberlanjutan dan keberhasilan program pada masa mendatang. Hasil tersebut terlihat dari Tabel 2 yang menunjukkan bahwa indikator pernyatan minat menanam kedelai hitam memiliki ratarata skor 2,98 yang termasuk dalam kriteria "cukup berminat". Hasil penelitian sesjalan dengan yang dilaporkan oleh Ayunita dan Hapsari (2012) bahwa persepsi positif/baik akan menghasilkan partisipasi yang positif/baik (partisipasi aktif) juga. Selanjutnya setelah dilakukan pemaparan dan demo pembuatan olahan kedelai hitam juga terlihat bahwa sebagian besar anggota kelompok tani sasaran juga mengaggap bahwa cara pengolahannya mudah dilakukan.

\section{B. Pembuatan Demplot Percobaan Penanaman Kedelai Hitam}

Kegiatan ini diawali melalui tahapan-tahapan yaitu melakukan koordinasi dengan Kepala Kelurahan/Desa Kemumu Kabupaten Bengkulu Utara sekaligus meminta arahan untuk mendapatkan kelompok tani target. Atas dasar koordinasi ini maka dilakukan koordinasi dengan salah satu kelompok tani yang secara turun temurun berbudidaya tanaman padi sawah. Langkah berikutnya yaitu mendiskusikan kebutuhan luasan sawah dan lokasinya yang akan digunakan untuk pembuatan demplot dan peninjauan lokasi calon demplot percobaan (Gambar 1).

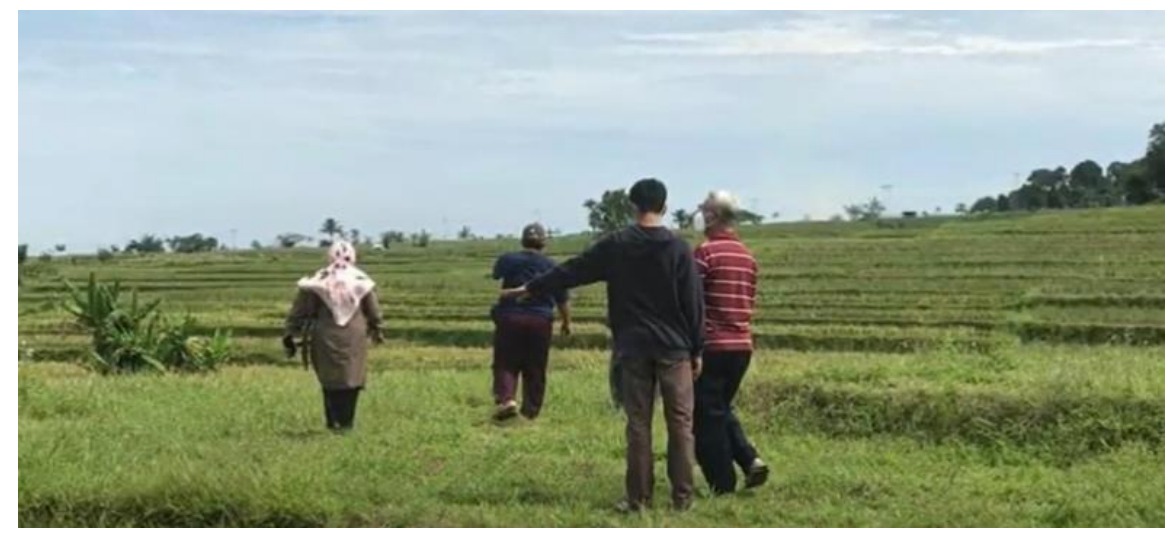

Gambar 1. Peninjauan lokasi demplot yang dilakukan oleh Tim dan Kelompok Tani

Setelah dilakukan penetapan lokasi dan luasan persawahan yang diperlukan maka dilakukan persiapan-persiapan yang meliputi : pengambilan sampel tanah untuk dilakukan analisis laboratorium untuk memperoleh nilai kesuburan kimiawinya, hasil analisis laboratorium akan digunakan sebagai dasar penentuan kebutuhan pupuk organik ataupun an organik. Adapun bahan yang disiapkan yaitu benih kedelai hitam (Glycine soja) varietas Detam 4, benih kedelai varietas Devatra 1 dan Devatra 2. Dua vararietas yang disebut terakhir merupakan hasil perakitan varietas kedelai (Glycine max L. Merr) dari dosen Fakultas Pertanian UNIB yang akan digunakan sebagai kontrol. Bahan lain yang disiapkan ialah legin. Legin (Legume Inoculant atau Legume Inoculum) adalah inokulum Rhizobium yang mengandung bakteri Rhizobium untuk inokulasi (menulari) tanaman legum. Bakteri Rhizobium adalah bakteri yang dapat bersimbiosis dengan tanaman legum, membentuk bintil akar, dan menambat nitrogen dari udara sehingga mampu mencukupi kebutuhan nitrogen $(\mathrm{N})$ tanaman sekurang-kurangnya sebesar $75 \%$.

Peranan Rhizobium terhadap pertumbuhan tanaman khususnya berkaitan dengan ketersediaan nitrogen bagi tanaman inangnya. Bakteri Rhizobium merupakan mikroba yang mampu mengikat nitrogen bebas yang berada di udara menjadi ammonia $\left(\mathrm{NH}_{3}\right)$ yang akan diubah menjadi asam amino yang selanjutnya menjadi senyawa nitrogen yang diperlukan tanaman untuk tumbuh dan berkembang, sedangkan Rhizobium sendiri 
memperoleh karbohidrat sebagai sumber energi dari tanaman inang (Sari dan Prayudyaningsih, 2015). Mekanisme kinerja Rhizobium dimulai dengan pembentukan koloni Rhizobium pada akar legum sebagai pengenalan terhadap inangnya. Spesies Rhizobium yang berbeda, berbeda pula inangnya. Proses infeksi dimulai dengan cara penetrasi bakteri ke dalam sel rambut akar. Infeksi dimulai dari rambut akar menyebabkan pertumbuhan rambut akar yang keriting akibat dari adanya auksin yang dihasilkan oleh bakteri. Benang infeksi terus berkembang sampai di kortek dan mengadakan percabangan. Percabangan ini menyebabkan jaringan kortek membesar yang dapat dilihat sebaga bintil akar (Novriani, 2011).

Lahan sawah yang digunakan dibersihkan dari rerumputan dan gulma lainnya, dan dilakukan pengolahan tanah. Setelah dilakukan pengolahan, dibuatan larikan-larikan yang nantinya akan digunakan sebagai media tumbuh tanaman kedelai (Gambar 2).

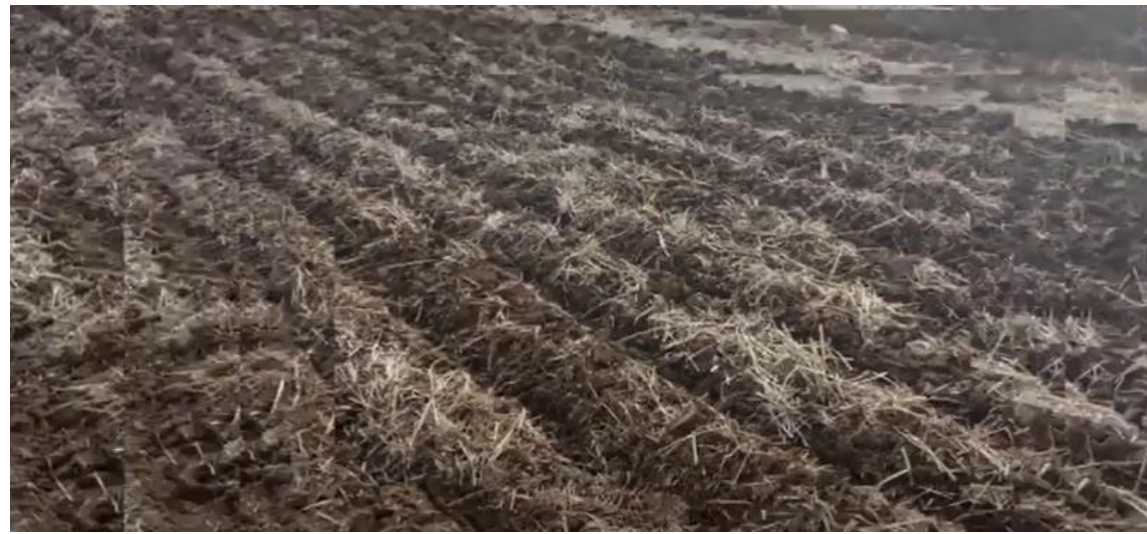

Gambar 2. Lahan sawah yang telah diolah

Berikutnya menyiapkan kotoran hewan berupa kotoran kambing yang nantinya akan diberikan pada setiap lubang tanam kedelai. Hasil analisis laboratorium terhadap sifat fisika dan kimia tanah sebagai dasar penentuan dosis pupuk an organik seperti terlihat pada tabel berikut.

Tabel 1. Hasil analisis sifat kimia dan fisik tanah

\begin{tabular}{clc}
\hline Sifat Kimia Tanah & & \\
\hline No. & \multicolumn{1}{c}{ Parameter } & Nilai \\
\hline 1. & N-total $(\%)$ & 0,23 \\
2. & $\%$ C & 0,88 \\
3. & P $(\mathrm{ppm})$ & 5,46 \\
4. & $\mathrm{~K}(\mathrm{me} / 100 \mathrm{~g})$ & 0,27 \\
5. & $\mathrm{KTK}(\mathrm{me} / 100 \mathrm{~g})$ & 21,20 \\
6. & $\mathrm{pH} \mathrm{KCl}$ & 4,57 \\
\hline Sifat Fisik Tanah & & \\
\hline 1. & Tekstur $(\%$ Pasir, \%Liat, \%Debu) & 54,$44 ; 19,55 ; 26,01$ \\
\hline
\end{tabular}

Berdasarkan hasil analisis tanah pada Tabel 1 maka lokasi demplot dapat dikategorikan memiliki potensi rendah untuk budidaya kedelai. Oleh karena itu pupuk an organik yang diberikan dalam kategori dosis tinggi yaitu $25 \mathrm{~kg}$ urea/ha, $150 \mathrm{~kg} / \mathrm{ha}$ SP-36, dan $100 \mathrm{~kg} \mathrm{KCl} / \mathrm{ha}$. Selain itu, benih kedelai juga diinokulasi dengan rhizobium dengan dosis $200 \mathrm{~g}$ untuk $40 \mathrm{~kg}$ benih. Hal tersebut dimaksud untuk membantu memnuhi kebutuhan $\mathrm{N}$ bagi tanaman.

Benih kedelai yang ditanam sebelumnya telah diberi inokulan rhizobium. Bersamaan dengan penanaman, setiap lubang tanam ditambahkan pupuk kotoran hewan, pupuk $\mathrm{N}$ setengah dosis. Pupuk $\mathrm{P}$ dan pupuk $\mathrm{K}$ diberikan sekaligus pada saat tanam 
kedelai. Jarak tanam yang digunakan untuk penanaman ini ialah $40 \mathrm{~cm}$ x $20 \mathrm{~cm}$. Pengairan bukan menjadi masalah karena lokasi demplot mendapat pengairan teknis dan curah hujan yang cenderung tinggi. Penanaman kedelai dapat dilihat pada Gambar 3.a. Saat tanaman memasuki umur 10 hari setelah tanam, dilakukan pemupukan $\mathrm{N}$ dosis kedua atau setengah dosis yang kedua (Gambar 3.b). Untuk menghindari adanya genangan air maka dilakukan pembuatan pembumbunan dan saluran drainase di sekeliling petak dan tengah petak (Gambar 3.c).

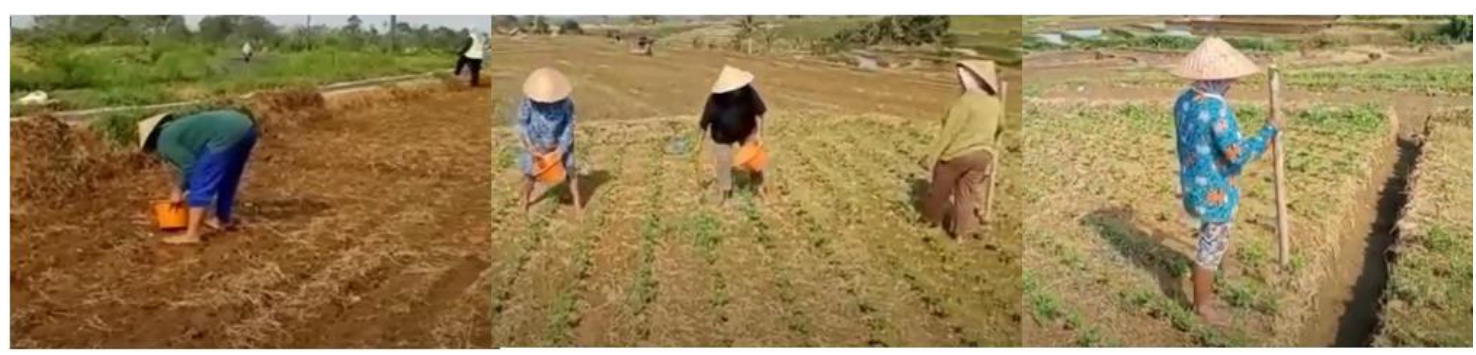

Gambar 3. Penanaman, pemupukan susulan, saluran drainase di tengah petakan

Tanaman kedelai di wilayah tropika seperti Indonesia tidak dapat dipisahkan dengan pertumbuhan gulma yang bertindak sebagai kompetitor tanaman. Oleh karena itu pada demplot ini dilakukan pengendalian gulma secara fisik dan hasilnya seperti terlihat pada Gambar 4.a. Selain itu, budidaya kedelai tak terlepas dari pengendalian hama dan penyakit tanaman yang menyerang tanaman kedelai. Pengendalian dilakukan dengan melakukan penyemprotan insektisida hayati. Hama yang menyerang tanaman kedelai pada lokasi demplot seperti terlihat pada Gambar 4.b.

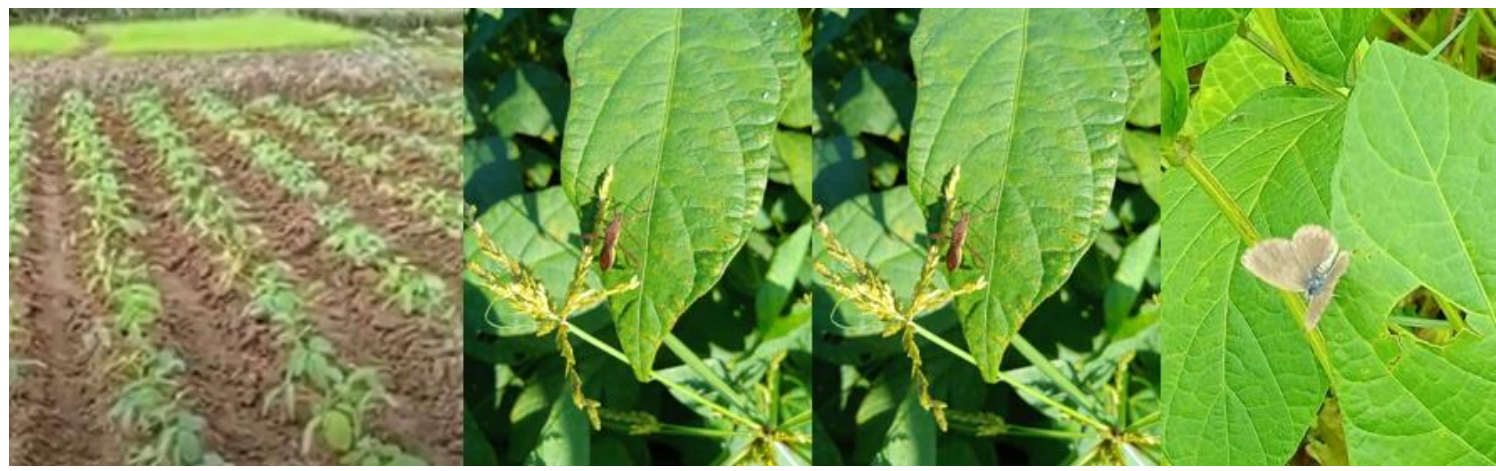

Gambar 4. Petakan yang telah dikendalikan pertumbuhan gulma, dan hama yang menyerang tanaman kedelai hitam.

Tanaman kedelai yang dibudidayakan tumbuh dengan baik hingga panen dilakukan. Data produksi hasil demplot percobaan tanaman kedelai hitam disajikan pada Tabel 2. Berdasarkan Tabel 2 terlihat bahwa bobot biji per tanaman yang dihasilkan adalah sebesar $11,4 \mathrm{~g}$ dengan hasil per ha mencapai 1,39 ton/ha. Hasil yang dicapai tersebut $55,6 \%$ sudah mampu menyamai dari potensi hasilnya yaitu 2,5 ton/ha. Hal tersebut sangatlah wajar karena budidaya kedelai hitam yang dilakukan di lokasi penelitian merupakan yang pertama, sehingga kedelai hitam masih tahap adaptasi dengan lingkungan.

Tabel 2. Keragaan hasil kedelai Detam 4

\begin{tabular}{lccc}
\hline Varietas & Bobot Biji per Tanaman $(\mathrm{g})$ & Hasil per ha (ton) & Potensi Hasil (ton/ha) \\
\hline Detam 4 & 11,14 & 1,39 & 2,5 \\
\hline
\end{tabular}


C. Pelatihan dan Pembuatan Olahan Kedelai Hitam

Kedelai hasil dari demplot percobaan selanjutnya dilakukan pengolahan menjadi tempe, tahu dan kecap. Hasil olahan yang dimaksud bertujuan untuk meningkatkan nilai ekonomi kedelai sehingga bisa berdampak pada meningkatnya sumber pendapatan bagi kelompok mitra. Sesuai dengan yang dilaporkan oleh Lizawati et al. (2021) bahwa peningkatan usaha mitra PKM dengan terciptanya diversifikasi aneka produk olahan kedelai, meningkatnya produksi produk olahan dan ketahanan produk serta meningkatnya nilai tambah produk olahan kedelai.

Selain itu Asmawati dan Herlambang (2020) juga melaporkan bahwa kegiatan pelatihan dapat meningkatka ketrampilan kelompok mitra dalam komoditi pertanian menjadi produk baru yang lebih bernilai ekonomis.

Pada kegiatan ini, anggota kelompok tani sasaran tidak hanya diberi pemaparan tentang cara pengolahannya, namun juga langsung dilakukan praktik pengolahan tempe dan tahu dibawah bimbingan tim pengabdian. Produk tempe, tahu dan kecap dipilih karena cara pembuatannya tergolong mudah dan tidak memerlukan alat khusus. Kelompok sasaran dalam kegiatan ini adalah ibu-ibu kelompok tani yang ada di Desa Kemumu. Harapannnya dengan bertambahnya kemampuan mengolah hasil biji kedelai menjadi tempe dan tahu dapat menambah penghasilan rumah tangga. Dalam pelaksanaannya nampak terlihat bahwa kelompok sasaran sangat antusias dalam mengikuti setiap arahan dan langka-langkah pembuatan tempe dan tahu. Hal tersebut mengindikasikan bahwa partisipasi kelompok mitra agar dapat menerapkan teknologi yang disampaikan tergolong tinggi. Kondisi tersebut dapat menjadi indikator keberhasilan program yang disampaikan. Sesuai dengan pernyataan Duaja et $a l$, (2018) bahwa salah satu faktor yang mempengaruhi keberhasilan suatu program adalah tingkat partisipasi mitra pemberdayaan masyarakat.

Hasil yang dicapai dalam kegiatan ini yaitu kelompok tani sasaran telah memahami dan mampu membuat tempe, tahu dan kecap dari bahan baku kedelai hitam. Ibrahim dan Sukmawati (2018) juga melaporkan bahwa melalui kegiatan pengabdian, membuat masyarakat khususnya asli warga papua mampu memproduksi tempe tingkat skala rumah tangga dengan cita rasa yang khas sesuai cita rasa tempe pada umumnya. Dengan mengetahui prinsip-prinsip

Pemanfaatan mikroorganisme dalam bidang industri pangan, maka dapat dijadikan bekal dalam berwirausaha oleh masyarakat asli papua dan atau masyarakat setempat. Selain itu, dilaporkan juga kegiatan pengabdian kepada masyarakat berupa sosialisasi dan pelatihan terbukti mampu meningkatkan ketrampilan kelompok mitra sasaran dalam membuat tahu (Widaningrum, 2015; Barus et al., 2019) dan kecap (Rahmawati dan Kurnia, 2009; Priyambdo et al., 2019).

Agar pembuatan olahan kedelai hitam memiliki dampak besar terhadap perekonomian kelompok mitra maka perlu dilakukan kegiatan lanjutan yaitu berupa pelatihan dan pemberian mesin-mesin penunjang produksi. Seperti yang dilaporan oleh Setyowibowo dan Prasetyo (2017) bahwa pelatihan kelompok mitra dalam menggunakan mesin pengupas kedelai, mesin pedal sealer, mesin pengiling kedelai, mesin press tahu manual dan kompor gas dapat meningatkan status mitra usaha dari usaha kecil ditingkatkan menjadi usaha mikro.

Langkah pertama dalam pembuatan tahu adalah pemilihan bahan baku berupa kedelai (dalam hal ini kedelai hitam). Kedelai dipilih yang memiliki kualitas bagus. Untuk memastikan kualitasnya maka tampihlah dulu kedelai agar mempermudah dalam penyortiran. Setelah dipilih, selanjutnya kedelai dicuci sampai bersih lalu direndam dengan air hangat selama 6-12 jam. Perendaman dilakukan sampai dengan tekstur kedelai 
mudah diolah dengan indikasi mengembang. Langkah selanjutnya adalah membersihkan kedelai dengan cara kembali dicuci berkali-kali sampai sebersih mungkin agar nantinya rasa tahu tidak masam. Selanjutnya kedelai dihancurkan sampai dengan halus. Alat yang digunakan cukup bervariasi, bisa menggunakan blender jika skala kecil maupun alat penggiling jika skala besar. Air sedikit ditambahkan sehingga kedelai berbentuk seperti bubur. Setelah itu, peras kedelai yang telah menjadi bubur dan ambil sarinya. Lakukan berkali kali agar sari kedelai dapat dibuat menjadi tahu yang halus. Kemudian masaklah bubur kedelai pada suhu sekitar $70{ }^{\circ} \mathrm{C}-80{ }^{\circ} \mathrm{C}$ atau sampai keluar gelembung-gelembung kecil pada saat kedelai dimasak. Aduk terus kedelai agar tidak menggumpal. Lalu tunggu adonan sampai uap panasnya hilang. Setelah itu saring kembali adonan tersebut sambil diaduk secara perlahan-lahan. Kemudian tambahkan bahan pembuat tahu yaitu batu tahu lalu aduk hingga rata. Proses ini akan dihasilkan gumpalan (endapan) tahu yang siap diproses. Setelah itu, masukkan adonan tahu dalam cetakan lalu dipress agar air yang terkandung keluar. Tahu dapat dipotong-potong sesuai dengan selera.

Langkah-langkah proses pembuatan tempe dari kedelai hitam adalah sebagai berikut: Sortir atau pilih kedelai terlebih dahulu. Selanjutnya dicuci dengan air bersih (usahakan dengan air mengalir). Kemudian rebus kedelai sampai benar-benar empuk. Setelah kedelai empuk, angkat lalu tiriskan dan siram dengan air dingin. Selanjutnya masukkan kedelai dalam baskom atau wadah lainnya dan diremas-remas dengan jari tangan, lalu tambahkan air. Buanglah kulit ari kedelai yang mengapung. Lakukan langkah tersebut berkali-kali sampai kulit ari kedelai benar-benar habis. Selanjutnya direbus kembali sampai air mendidih lalu angkat dan tiriskan sampai benar benar dingin. Setelah kedelai dingin lalau ditambahkan ragi dan diaduk hingga rata. Ragi yang dibutuhkan untuk $1 \mathrm{~kg}$ kedelai adalah $\pm 2 \mathrm{~g}$ saja. Selanjutnya kedelai yang telah dicampur dengan ragi dimasukkan kedalam wadah, misalnya plastik. Lalu tutup rapat plastik dan beri lubang udara. Kemudian letakkan ditempat gelap agar kedelai terfermentasi selama \pm 2 malam. Jangan lupa ciprati dengan air untuk menjaga kelembaban agar proses fermentasi berjalan sempurna. Setelah 2 malam cek apakah tempe sudah jadi, kalau belum lanjutkan fermentasi dan cek skala berkala sampai dengan tempe telah jadi dan siap untuk diolah sebagai bahan makanan.

Proses pembuatan kecap diawali dengan memilih biji kedelai hitam yang berkualitas kemudian dicuci dan direndam dengan air selama 24 jam. Lalu dimasak tanpa penutup dalam panci selama 4 hingga 5 jam dengan api sedang-tinggi. Setelah biji kedelai matang selanjutnya dihaluskan menjadi pasta halus menggunakan food processor atau lesung atau blender. Selanjutnya menambahkan tepung terigu kemudian diuleni adonan hingga kedelai tercampur rata dengan tepung terigu. Langkah selanjutnya adalah proses fermentasi. Dalam proses fermentasi maka tambahkanlah koji dengan cara menaburkan ke dalam adoanan kedelai. Setelah itu, simpan adonan kedelai yang telah ditambah koji di tempat yang jarang dijangkau. Setelah proses fermentasi selesai, langkah selanjutnya adalah menyaring dan mempasteurisasi kecap buatan sendiri untuk menghilangkan bakteri berbahaya. Proses penyaringan bisa menggunakan kain katun yang tipis lalu padatan ditekan dengan spatula sampai semua cairan keluar. Selanjutnya cairan hasil saringan dipanaskan dengan api sedang-besar dengan suhu $79{ }^{\circ} \mathrm{C}$ selama 20 menit. Setelah itu biarkan sampai dingin, lalu masukkan kecap yang telah jadi ke dalam wadah (bisa berupa botol). Pada akhir kegiatan dilakukan sesi foto bersama antara tim pengabdian dan anggota kelompok tani sasaran (Gambar 5). 


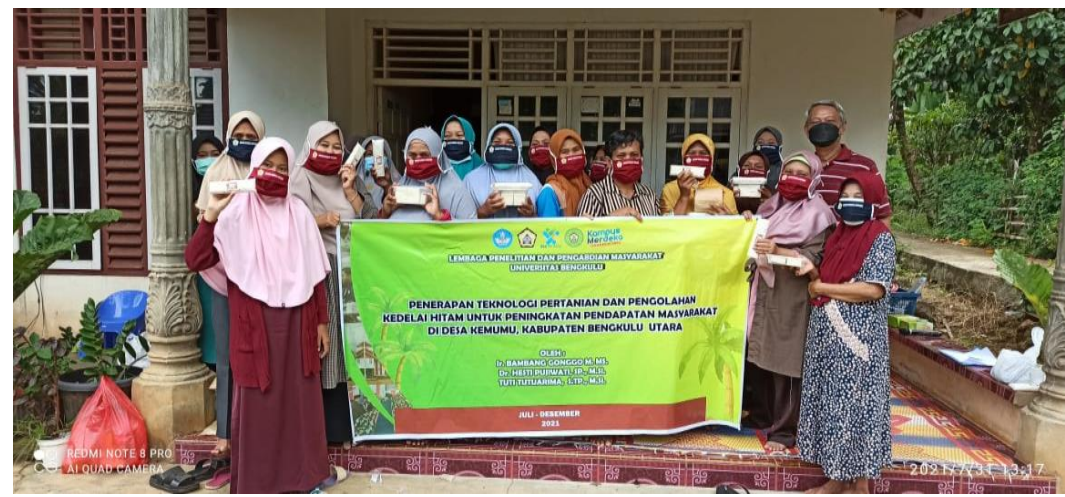

Gambar 5. Kelompok Wanita Tani peserta pembuatan tahu dan tempe

\section{KESIMPULAN}

Kegiatan pendidikan dan penyuluhan yang dilakukan tim pengabdian mampu meningkatkan pengetahuan tentang kedelai hitam baik teknik tanam maupun pengolahan hasil bijinya. Budidaya tanaman kedelai dan pembuatan olahan biji kedelai menjadi tempe, tahu dan kecap telah berhasil dilakukan oleh kelompok tani Desa Kemumu, Bengkulu Utara. Hasil yang dicapai oleh kedelai hitam varietas Detam 4 adalah sebesar 1,39 ton/ha. Untuk menindaklanjuti kegiatan ini, maka saran yang diajukan meliputi: (1) kedepannya anggota kelompok tani sasaran diharapkan tetap menjalankan praktik budidaya kedelai hitam dengan skala lebih luas (2) anggota kelompok tani sasaran untuk tetap membuat tempe dan kedelai dengan skala industri sehingga bisa menambah pemasukan rumah tangga, (3) kepada pihak pemerintah agar dapat memberikan saluran dana guna memenuhi sumberdaya peralatan yang memadai dalam produksi tahu dan tempe skala industri.

\section{DAFTAR PUSTAKA}

Ayunita, D., dan T.D. Hapsari. 2012. Analisis Persepsi dan Partisipasi Masyarakat Pesisir pada Pengelolaan KKLD Ujungnegoro Kabupaten Batang. Jurnal SEPA. 9(1) : 117-124

Asmawati, E dan A. Herlambang. 2020. Pemberdayaan masyarakat dalam pengolahan hasil pertanian ubi jalar Di Desa Selotapak. PEDULI: Jurnal Ilmiah Pengabdian Pada Masyaraka. 4(1) : 1-12

Astuti, M., A. Meliala, F.S. Dalais, and M.L. Wahlqvist. 2009. Tempe, a nutritious and healthy food from Indonesia. Asia Pacific J. Clin. Nutr. 9(4): 322-325

Barus, T., Y.R.E. Wulandari, R.A. Hutagalung, dan A.W. Gunawan. 2019. Pelatihan membuat tahu yang sehat pada WKRI Paroki St. Maria Fatima, Sentul City, Bogor. Jurnal Bakti Masyarakat Indonesia. 2(1) : 145-154

Devi AMK, Gondhi M, Giridhar SP, Rajasekaran T, Ravishankar GA. 2009. Functional attributes of soybean seeds and product with reference to isoflavone content and antioxidant activity. Food Chemistry 14: 771-776

Duaja, M, D., Buhaira, Nelyati, dan E. Kartika. 2018. Pemberdayaan Masyarakat Desa Sri Agung untuk Meningkatkan Ketahanan Pangan dengan Introduksi Padi Hitam di Pekarangan. Riau Journal of Empowerment, 1(1), 37-43

Ibrahim dan Sukmawati. 2018. Sosialisasi pembuatan tempe skala industri rumahtangga pada masyarakat asli Papua di Kelurahan Malanu Distrik Malaimsimsa Kota Sorong Papua Barat. MARTABE : Jurnal Pengabdian Masyarakat. 1(3): 93-88 
Indrawijaya, B., Paradiba, A., Murni, S.A., 2017. Uji organoleptik dan tingkat ketahanan produk tahu berpengawet kitosan. Jurnal Ilm. Tek. Kim. 1(2) : 1-7

Irwanto, R., D.R. Adawiyah, dan F.R. Zakaria. 2016. Peran fisiologis sari kedelai hitam diperkaya mikroenkapsulan minyak sawit mentah pada penderita diabetes melitus tipe 2. Jurnal Teknologi dan Industri Pangan, 27 (1): 1- 9.

Jeng TL, Y.J Shih, M.T Wu, dan J.M Sung. 2010. Comparison of flavonoids and anti oxidative activities in seed coat, embryonic axis and cotyledon of black soybeans. Food Chemistry. $123: 1112-1116$

Lizawati, E. Kartika, M.D, H. Setyaji, dan Gusniwati. 2021. Pemberdayaan kelompok tani kedelai melalui penerapan teknologi pengolahan kedelai untuk meningkatkan pendapatan petani di Desa Marga Mulya Kecamatan Rantau Rasau. Riau Journal Of Empowerment. 4 (2), 59-68

Muangthai, P, U. P. Suwunna, dan W. Patumpai. 2009. Development Of Healthy Soy Sauce From Pigeon Pea And Soybean. Asian Journal of Food and Agro Industry. 2: 291-301

Mueller. 2012. Soy intake and risk of type 2 diabetes mellitus in Chinese Singaporeans. Soy intake and risk of type 2 diabetes. Eur J nutr, 51(8): 1022-40

Novriani. 2011. Peranan rhizobium dalam meningkatkan ketersediaan nitrogen bagi tanaman kedelai. Agronobis. 3(5) : 35-42

Priyambodo, S., I.A. Lestarini, R. Basuki, R. Cholidah dan Palgunadi. 2019. Pelatihan pembuatan tempe kedelai hitam pengrajin tempe Kelurahan Abian Tubuh. Jurnal Pengabdian Magister Pendidikan IPA. (1) 2: 8-11

Rahmawati, S., dan P. Kurnia. 2009. Pembuatan kecap dan cookies ampas tahu sebagai upaya peningkatan potensi masyarakat di sentra industri tahu Kampung Krajan, Mojosongo, Surakarta. WARTA. 12(1): 1-7

Sari, R dan R. Prayudyaningsih. 2015. Rhizobium: pemanfaatannya sebagai bakteri penambat nitrogen. Info Teknis EBONI. 12(1) 51-64

Setyowibowo, S dan A. Prasetyo. 2017. Pengembangan industri tahu dan tempe sebagai alternatif pangan di Desa Curahmalang Kecamatan Rambipuji Kabupaten Jember. PEDULI - Jurnal Ilmiah Pengabdian Pada Masyarakat. 1(2): 11-19

Tanuwijaya, L.K., A.P. Gita., I.I., Ummi., T.S Kusuma dan A. Ruhana. 2016. Potensi "khimelor" sebagai tepung komposit tinggi energi tinggi protein berbasis pangan lokal (Health potential of "khimelor" as composite fluor having both high energy and high protein level based on local food). Indonesian Journal of Human Nutrition, 3(1):71-79.

Widaningrum, I. 2015. Teknologi pembuatan tahu yang ramah lingkungan (bebas limbah). Jurnal Dedikasi. 12(1) : 14-21

Yanti, Y., M. Busniah, T. Habazar, dan Z. Syarief. 2017. Pengembangan pertanian organic melalui budidaya tanaman palawija dengan aplikasi teknologi rizobakteri indigenos di Nagari Sungai Durian Kabupaten Solok. Logista-Jurnal Ilmiah Pengabdian kepada Masyarakat, 1(2) : 88-94

Zakaria, F.R., D.P.R. Firdaus, dan N.D. Yuliana. 2016. Konsumsi tahu kedelai hitam untuk memperbaiki nilai sgot/sgtp dan aktivitas antioksidan plasma penderita diabetes tipe 2. Jurnal Pangan, 25(2): 95-104. 